\title{
Formulation, stability and analytical method validations of combined St. John's wort and valerian root dry extracts in solid oral dosage forms
}

\author{
İlker DEMİRBLAT 1, 2 * (D), Murat KARTAL 1 (D) \\ 1 Center of Education, Practice and Research in Phytotherapy, Bezmialem Vakıf University, 34093 Fatih, İstanbul, \\ Turkey. \\ 2 Department of Pharmaceutical Chemistry, Faculty of Pharmacy, Marmara University, 34668 Haydarpaşa, İstanbul, \\ Turkey. \\ * Corresponding Author. E-mail: idemirbolat@bezmialem.edu.tr (İ.D.); Tel. +90-216-523 22 88-18 81.
}

Received: 18 March 2019 / Revised: 10 June 2019 / Accepted: 12 June 2019

\begin{abstract}
Minor depression and sleep disorders are common problems in modern societies. There are prescription medicines and herbal remedies to ease the symptoms. St. John's wort is often used to treat mild depression and valerian root is recommended as a sedative for centuries. Nowadays there is an increasing interest for herbal medicines and therefore the herbal products are becoming more and more popular. As dietary supplement retailers selling low quality products -or even don't contain what's claimed on the label- quality becomes the major concern. The legislation to conventional medicines applies to traditional herbal medicines too, which makes registered herbal medicines reliable in production and quality. A CTD application dossier which contains quality data in module 3 should be provided while registering a herbal medicine in EU. In this study we developed a stable formulation and validated two separate methods to quantify the herbal extract amounts in solid oral dosage forms which contains St. John's Wort and valerian dry extract as active ingredients to comply CTD module 3 requirements.
\end{abstract}

KEYWORDS: St. John's Wort; valerian; validation; formulation; stability.

\section{INTRODUCTION}

Aerial parts of St. John's Wort (Hypericum perforatum L.), a member of genus Hypericum L., has long been used for its health benefits. Hippocrates and Galen suggested this herb for intestinal worms, woundhealing agent and as antimalarial. Paracelsus recommended the herb for mild depression and melancholy [1, 2]. Dry extract of St. John's Wort (SJW) is indicated for symptomatic treatment of mild depressive episodes. Other therapeutic indications for traditional and well-established uses of SJW were mentioned in European Medicines Agency (EMA) 2008 report [3].

Underground parts of Valeriana officinalis L. is the drug so called valerian. Hippocrates recommended its medicinal properties for digestive disorders, nausea, and menstrual cramps. Galen was the first who described the sleep-aid properties [4-6]. In German Commission E monographs, the valerian root extract is an approved herbal medicine for its sedative and sleep-aid activity [7]. Valerian root dry extract (VDE) is also used to treat sleep disorders, temporary insomnia, mood disorders and mental stress as described in EMA report [8].

In European Pharmacopoeia (EP), SJW is quantified to antraquinone derivatives called hypericins. EP content range for total hypericins is between $0.1 \%$ and $0.3 \%$, expressed as hypericin [9]. VDE is also described in EP and the content is standardised to minimum 0.25 percent of sesquiterpenic acids, expressed as valerenic acid [10].

Traditional herbal medicinal products are regulated by international or local authorities same way as the conventional medicines. Registration of herbal and conventional medicines requires application dossiers known as common technical document (CTD), a mandatory format for new drug applications. The CTD consists of five modules and the third one contains all the required manufacturing and production quality data about the product $[11,12]$.

How to cite this article: Demirbolat i, Kartal M. Formulation, stability and analytical method validations of combined St. John's wort and valerian root dry extracts in solid oral dosage forms. J Res Pharm. 2019; 23(5): 812-821. 
There are several traditional herbal medicinal products which contains SJW and VDE together with the aim of working synergistically. In this study we developed a stable oral formulation and validated two separate HPLC methods to quantify hypericins and valerenic acids.

\section{RESULTS AND DISCUSSION}

\subsection{Optimization of HPLC methods for hypericins and valerenic acids}

Quantifying hypericins content of SJW according to EP monograph relies on octadecylsilyl (C18) silica gel columns. Various C18 columns were used to achieve the best separation and peak shapes using the same mobile phase as EP suggested. With higher carbon loaded columns peak tailings were unacceptable so a $9.8 \%$ carbon loaded $300 \mathrm{~mm}, 3.9 \mathrm{~mm} \times 10 \mu \mathrm{m}$ column was selected as the analytical column.

Method described in the EP for VDE was not suitable to quantify valerenic acids in SJW matrix and there is no defined method in the literature either. So a relatively long method was developed to achieve the separation of acetoxyvalerenic acid from the phenolic fraction of SJW with a $15 \%$ carbon loaded $250 \mathrm{~mm}, 4.6$ $\mathrm{mm} \times 5 \mu \mathrm{m}$ C18 column. Both method parameters were given in Table 1 .

Table 1. Method parameters for hypericins and valerenic acids methods.

\begin{tabular}{|c|c|c|}
\hline & Hypericins & Valerenic Acids \\
\hline System & Shimadzu HPLC Prominence & Shimadzu HPLC Prominence \\
\hline Column & $\begin{array}{l}\text { Waters } \mu \text { Bondapak } \mathrm{C} 18,300 \mathrm{~mm} \times \\
3.9 \mathrm{~mm} \times 10 \mu \mathrm{m}\end{array}$ & $\begin{array}{c}\text { GLSciences ODS-3, } 250 \mathrm{~mm} \times 4.6 \mathrm{~mm} \\
\times 5 \mu \mathrm{m}\end{array}$ \\
\hline Flow & $1 \mathrm{~mL} / \mathrm{min}$ & $1.5 \mathrm{~mL} / \mathrm{min}$ \\
\hline Detection & $590 \mathrm{~nm}$ & $220 \mathrm{~nm}$ \\
\hline Enjection & $20 \mu \mathrm{L}$ & $20 \mu \mathrm{L}$ \\
\hline Column Oven & $40^{\circ} \mathrm{C}$ & $40^{\circ} \mathrm{C}$ \\
\hline Mobil Phase & Ethyl acetate:Buffer & Mobile Phase A: $5 \mathrm{~g} / \mathrm{L} \mathrm{H}_{3} \mathrm{PO}_{4}$ \\
\hline Buffer Solution & $\begin{array}{c}\text { Solution:Methanol } \\
\text { (39:41:160 V/V/V). } \\
\text { 15.6 g/L NaH} \mathrm{PO}_{4} \\
\text { pH: } 2 \text { adjusted with } \mathrm{H}_{3} \mathrm{PO}_{4}\end{array}$ & Mobile Phase B: Acetonitrile \\
\hline Flow Rate & Isocratic & $\begin{array}{cc}\begin{array}{c}\text { Time } \\
(\mathrm{min})\end{array} & \begin{array}{c}\text { Mobil Phase B } \\
(\mathrm{V} / \mathrm{V} \%)\end{array} \\
0-1 & 45 \rightarrow 45 \\
1-25 & 45 \rightarrow 55 \\
25-40 & 55 \\
40-41 & 55 \rightarrow 45 \\
41-50 & 45\end{array}$ \\
\hline
\end{tabular}

\subsection{Method validation}

Method validation was performed according to International Conference on Harmonization (ICH) Q2(R1) Validation of Analytical Procedures: Text and Methodology guidelines [13].

\subsubsection{Product and placebo}

The products are manufactured according to the formulation given in Table 2.

Table 2. Unit formula per capsule.

\begin{tabular}{lc}
\hline Ingredient & Amount for one capsule (mg) \\
\hline St John's Wort Dry Extract & 300 \\
Valerian Root Dry Extract & 100 \\
Maldex Pharma (Maltodextrine) & 90 \\
Ligamed MF-2-V (Magnesium stearate) & 5 \\
HDK N20 Pharma (Silicon dioxide) & 5 \\
TOTAL & 500 \\
\hline
\end{tabular}




\subsubsection{Specificity}

The ICH documents define specificity as the ability to assess the analyte in the presence of matrix components. To achieve specificity for both methods; solvents, mobile phases, placebos of the related methods and reference substances (CRS) were used. Specificity results and the chromatograms of the products are represented in Table 3, Table 4 and Figure 1 respectively.

Table 3. The results illustrating specificity of SJW hypericins.

\begin{tabular}{lccc}
\hline Sample & Pseudohypericin Retention Time & Hypericin retention time & Resolution \\
\hline SJW dry extract CRS & 5.32 & 10.08 & 9.08 \\
Placebo & - & - & - \\
Solvent (Methanol) & - & - & - \\
Mobile Phase & - & - & - \\
Product & 5.32 & 10.08 & 9.1 \\
\hline
\end{tabular}

Table 4. The results illustrating specificity of VDE valerenic acids.

\begin{tabular}{lccc}
\hline Sample & $\begin{array}{c}\text { Acetoxyvalerenic acid retention } \\
\text { time }\end{array}$ & $\begin{array}{c}\text { Valerenic acid retention } \\
\text { time }\end{array}$ & Resolution \\
\hline Valerian dry extract & 17.65 & 35.39 & 29.7 \\
CRS & - & - & - \\
Placebo & - & - & - \\
Solvent (Methanol) & - & - & - \\
Mobile Phase & 17.69 & 35.43 & 29.7 \\
Product & & &
\end{tabular}
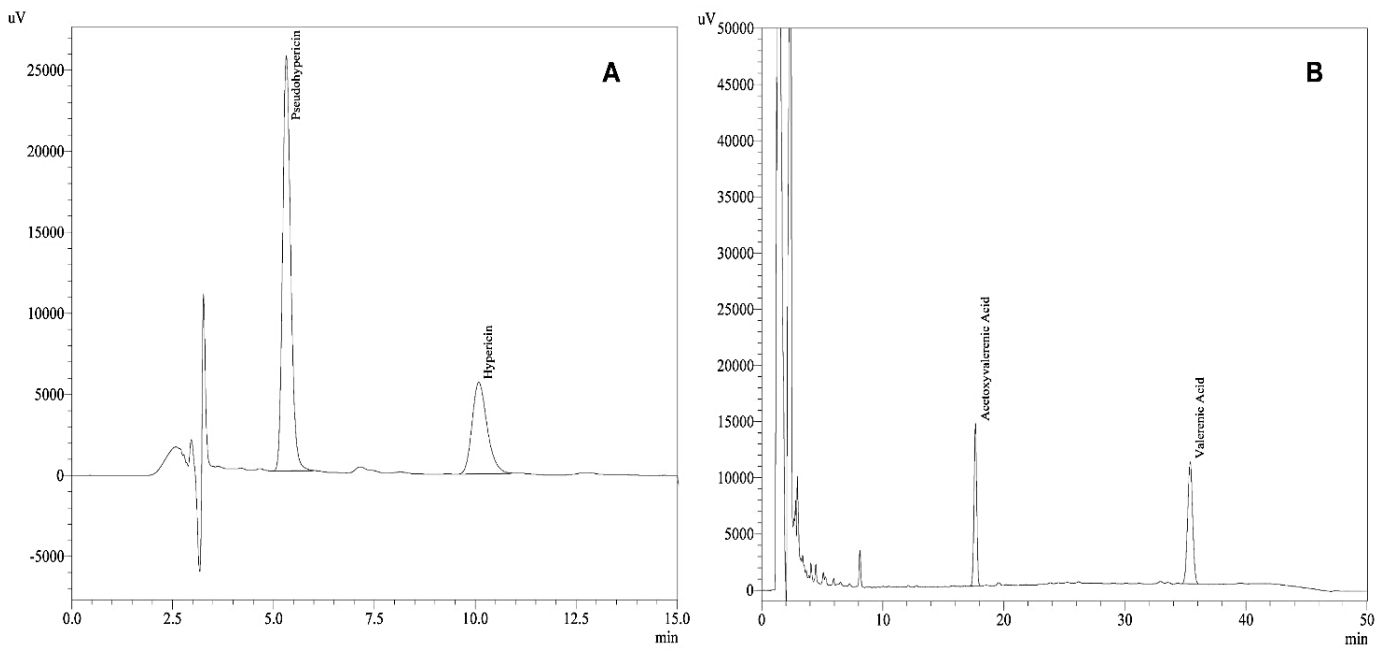

Figure 1. Chromatogram of (A) hypericins of SJW and (B) valerenic acids of VDE standards.

\subsubsection{System repeatability, system suitability, range and linearity}

To achieve system repeatability, system suitability and linearity; $50 \%, 80 \%, 100 \%, 120 \%$ and 150\% concentration of SJW and VDE reference substances (CRS) were prepared according to the method described in material and methods section. $100 \%$ concentration solution was injected six times to achieve both linearity, system repeatability and system suitability. Table 5 and 6 illustrate the results for both hypericins and valerenic acids while Figure 2 demonstrates the calibration curves for linearity tests. Acceptance for the range test was based on the following: range of the method should be linear, accurate, and repeatable between the $80 \%$ and the $120 \%$ of the solution and the results comply with the criteria. 
Table 5. System repeatability, system suitability, range and linearity data for hypericins of SJW between concentration and peak areas. The calculated RSD\% was $\leq 2.0$ for system repeatability and the system suitability tests comply with the criteria.

\begin{tabular}{lcccc}
\hline Concentration & $\begin{array}{c}\text { Pseudohypericin } \\
\text { area }\end{array}$ & $\begin{array}{c}\text { Hypericin } \\
\text { area }\end{array}$ & $\begin{array}{c}\text { Total hypericins } \\
\text { area }\end{array}$ & $\begin{array}{c}\text { Average hypericins } \\
\text { area }\end{array}$ \\
\hline 50\% (35 mg SJW & 151099 & 61191 & 212290 & 211998 \\
dry extract CRS) & 150681 & 61006 & 211687 & \\
& 150751 & 61267 & 212018 & 343160 \\
$80 \%$ (56 mg SJW & 243532 & 99401 & 342933 & \\
dry extract CRS) & 243669 & 99415 & 343084 & \\
& 243673 & 99791 & 343464 & 430014 \\
& 304697 & 125046 & 429743 & \\
$100 \%$ (70 mg SJW & 304941 & 124843 & 429784 & \\
dry extract CRS) & 305332 & 124904 & 430236 & \\
& 305073 & 124913 & 429986 & \\
& 305147 & 125309 & 430456 & \\
$120 \%$ (84 mg SJW & 305064 & 124813 & 429877 & \\
dry extract CRS) & 368094 & 151735 & 519829 & 649339 \\
$150 \%$ (105 mg & 368249 & 150212 & 518461 & \\
SJW dry & 368291 & 150965 & 519256 & \\
extract CRS) & 460169 & 189256 & 649425 & 649457 \\
\hline
\end{tabular}

Table 6. System repeatability, system suitability, range and linearity data for valerenic acids of VDE between concentration and peak areas. The calculated RSD \% was $\leq 2.0$ for system repeatability and the system suitability tests comply with the criteria.

\begin{tabular}{lcccc}
\hline Concentration & $\begin{array}{c}\text { Axetoxyvalerenic } \\
\text { acid area }\end{array}$ & $\begin{array}{c}\text { Valerenic } \\
\text { acid area }\end{array}$ & $\begin{array}{c}\text { Total valerenic } \\
\text { acids area }\end{array}$ & $\begin{array}{c}\text { Average valerenic } \\
\text { acids area }\end{array}$ \\
\hline $50 \%$ (25 mg Valerian & 113532 & 157834 & 271366 & 272100 \\
dry extract CRS) & 114394 & 158613 & 273007 & \\
& 113668 & 158258 & 271926 & 441660 \\
$80 \%$ (40 mg Valerian & 184978 & 256604 & 441582 & \\
dry extract CRS) & 184658 & 256646 & 441304 & \\
& 185204 & 256889 & 442093 & 538765 \\
& 224913 & 313390 & 538303 & \\
$100 \%$ (50 mg Valerian & 224953 & 312923 & 537876 & \\
dry extract CRS) & 225483 & 313181 & 538664 & \\
& 225093 & 312730 & 537823 & \\
& 226156 & 313833 & 539989 & \\
$120 \%$ (60 mg Valerian & 225971 & 313962 & 539933 & \\
dry extract CRS) & 269122 & 373887 & 643009 & \\
& 269334 & 374059 & 643393 & \\
$150 \%$ (75 mg Valerian & 269358 & 374957 & 644315 & \\
dry extract CRS) & 334234 & 464471 & 798705 & \\
\end{tabular}

\subsubsection{Accuracy}

The accuracy of method was determined by means of recovery data. For this purpose units were produced according to Table 13 in materials and methods section. Three sets of samples were prepared for each concentration and each sample tested for twice. The amount of extracts per capsules was calculated according to the formulas given below. Table 7 and 8 demonstrate the accuracy studies. 
A1: area of pseudohypericin in product, A2: area of hypericin in product, $\mathrm{m} 1$ : sample in test solution in grams, $\mathrm{p} 1$ : percentage of total hypericins in raw material, A3: area of hypericin in the CRS, $\mathrm{m} 2$ : CRS in in reference solution in grams, p2: percentage of hypericin in CRS. (Total hypericins in the raw materials should be quantified before use).

$$
\text { VDE in Capsules }(g)=\frac{(\mathrm{A} 1+\mathrm{A} 2) \times \mathrm{m} 2 \times \mathrm{p} 2}{\mathrm{~A} 3 \times \mathrm{m} 1 \times \mathrm{p} 1}
$$

A1: area of acetoxyvalerenic acid in product, A2: area of valerenic acid in product, $\mathrm{m} 1$ : sample in test solution in grams, p1: percentage of total valerenic acids in raw material, A3: area of valerenic acid in the CRS, $\mathrm{m} 2$ : CRS in reference solution grams, p2: percentage of valerenic acid in CRS. (Acetoxyvalerenic acid and valerenic acids in the raw materials should be quantified as valerenic acid before use).
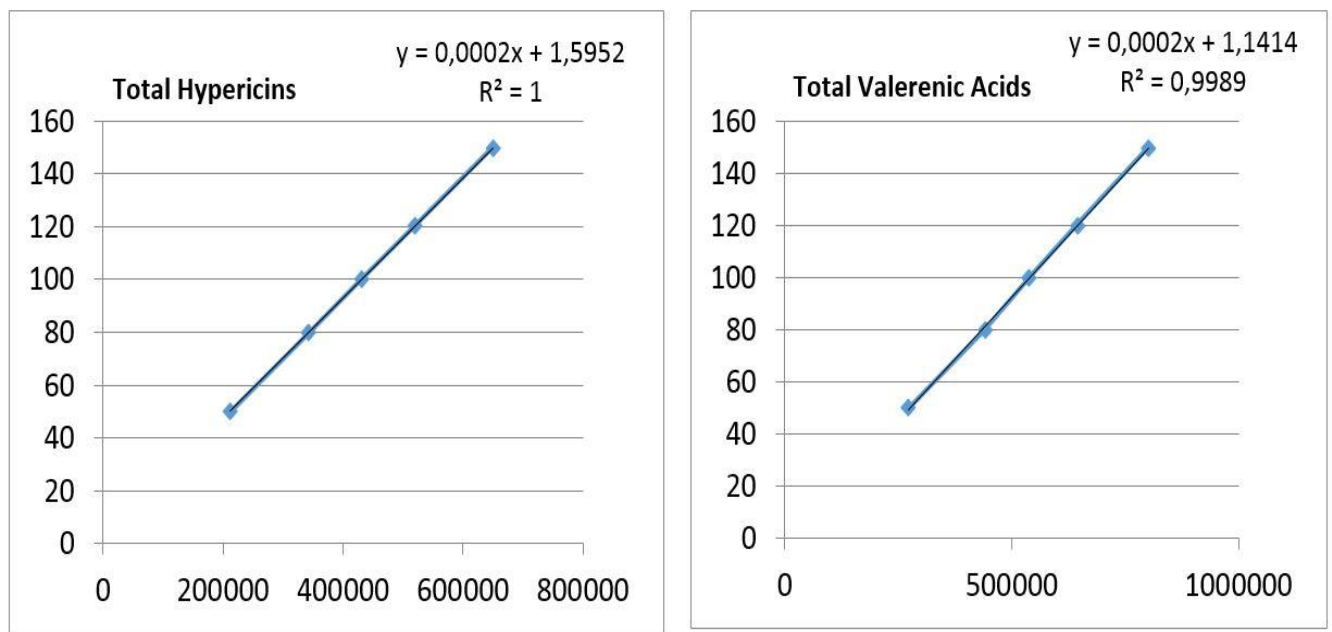

Figure 2. Calibration curve for hypericins and valerenic acids.

Table 7. Accuracy studies for SJW.

\begin{tabular}{|c|c|c|c|}
\hline $\begin{array}{l}\text { Sample } \\
\text { Concentration }\end{array}$ & $\begin{array}{c}\text { SJW in Capsules } \\
(\mathrm{mg})\end{array}$ & $\begin{array}{l}\text { Analysed SJW in } \\
\text { Capsules (mg) }\end{array}$ & Recovery \% \\
\hline \multirow{2}{*}{$80 \%$} & 240 & 242.90 & 101.2 \\
\hline & 240 & 241.58 & 100.7 \\
\hline \multirow{2}{*}{$80 \%$} & 240 & 244.22 & 101.8 \\
\hline & 240 & 242.90 & 101.2 \\
\hline \multirow{2}{*}{$80 \%$} & 240 & 245.28 & 102.2 \\
\hline & 240 & 245.01 & 102.1 \\
\hline \multirow{2}{*}{$100 \%$} & 300 & 299.74 & 99.9 \\
\hline & 300 & 299.74 & 99.9 \\
\hline \multirow{2}{*}{$100 \%$} & 300 & 300.53 & 100.2 \\
\hline & 300 & 299.48 & 99.8 \\
\hline \multirow{2}{*}{$100 \%$} & 300 & 302.11 & 100.7 \\
\hline & 300 & 301.58 & 100.5 \\
\hline \multirow{2}{*}{$120 \%$} & 360 & 362.37 & 100.7 \\
\hline & 360 & 362.10 & 100.6 \\
\hline \multirow{2}{*}{$120 \%$} & 360 & 358.95 & 99.7 \\
\hline & 360 & 359.74 & 99.9 \\
\hline \multirow{2}{*}{$120 \%$} & 360 & 364.47 & 101.2 \\
\hline & 360 & 363.68 & 101.0 \\
\hline
\end{tabular}


Table 8. Accuracy studies for VDE.

\begin{tabular}{lccc}
\hline Sample Concentration & $\begin{array}{c}\text { VDE in Products \% } \\
(\mathbf{w} / \mathbf{w})\end{array}$ & $\begin{array}{c}\text { Analysed VDE in } \\
\text { Products } \mathbf{\%}(\mathbf{w} / \mathbf{w})\end{array}$ & Recovery \% \\
\hline \multirow{2}{*}{$80 \%$} & 80 & 80.78 & 100.9 \\
& 80 & 81.44 & 101.8 \\
$80 \%$ & 80 & 79.78 & 99.7 \\
& 80 & 79.89 & 99.9 \\
$80 \%$ & 80 & 80.33 & 100.4 \\
& 80 & 81.22 & 101.5 \\
$100 \%$ & 100 & 101.89 & 101.9 \\
& 100 & 101.56 & 101.6 \\
$100 \%$ & 100 & 99.11 & 99.1 \\
& 100 & 99.56 & 99.6 \\
$100 \%$ & 100 & 101.44 & 101.4 \\
& 100 & 101.22 & 101.2 \\
$120 \%$ & 120 & 120.11 & 100.1 \\
& 120 & 119.89 & 99.9 \\
$120 \%$ & 120 & 120.33 & 100.3 \\
& 120 & 120.22 & 100.2 \\
& 120 & 120.56 & 100.5 \\
& 120 & 120.78 & 100.6 \\
\hline
\end{tabular}

\subsubsection{Precision}

The precision of an analytical procedure is the degree of agreement among individual test results when the procedure is applied repeatedly to multiple samplings of a homogeneous sample. Precision of the method assessed in terms of repeatability, intermediate precision and reproducibility. Reproducibility refers to the use of the analytical procedure in different laboratories, as in a collaborative study. Intermediate precision (also known as ruggedness) expresses within-laboratory variation, as on different days, or with different analysts or equipment within the same laboratory. Repeatability refers to the use of the analytical procedure within a laboratory over a short period of time using the same analyst with the same equipment. Table 9 shows intermediate precision and repeatability data while Table 10 demonstrates the reproducibility of the method.

Table 9. The assessment of repeatability and intermediate precision for SJW and VDE.

\begin{tabular}{lll}
\hline SJW in Capsules (mg) & Analyst-1 & Analyst-2 \\
\hline 300 & 304 & 305 \\
300 & 303 & 302 \\
300 & 295 & 298 \\
300 & 298 & 302 \\
300 & 301 & 303 \\
300 & 307 & 306 \\
\hline \multicolumn{4}{l}{ Statistics } \\
RSD $\%$ SD & $300 \pm 4.32$ & $300 \pm 2.66$ \\
\hline VDE in Capsules (mg) & 1.43 & 0.93 \\
\hline 100 & Analyst-1 & Analyst-2 \\
100 & 102 & 98 \\
100 & 102 & 99 \\
100 & 98 & 102 \\
100 & 101 & 100 \\
\hline & 99 & 101 \\
\hline Mean \pm SD & 98 & 97 \\
RSD $\%$ & Statistics & $100 \pm 1.87$ \\
\hline
\end{tabular}


Table 10. Data obtained from reproducibility study of SJW and VDE using same type columns with different serial numbers.

\begin{tabular}{|c|c|}
\hline SJW in Capsules (mg) & Analyst-1 \\
\hline 300 & 301 \\
\hline 300 & 303 \\
\hline 300 & 298 \\
\hline 300 & 301 \\
\hline 300 & 305 \\
\hline 300 & 302 \\
\hline \multicolumn{2}{|c|}{ Statistics } \\
\hline Mean \pm SD & $300 \pm 2.33$ \\
\hline RSD $\%$ & 0.77 \\
\hline VDE in Capsules (mg) & Analyst-1 \\
\hline 100 & 100 \\
\hline 100 & 98 \\
\hline 100 & 103 \\
\hline 100 & 102 \\
\hline 100 & 99 \\
\hline 100 & 102 \\
\hline \multicolumn{2}{|c|}{ Statistics } \\
\hline Mean \pm SD & $100 \pm 1.96$ \\
\hline RSD $\%$ & 1.95 \\
\hline
\end{tabular}

\subsubsection{Limit of Detection and Limit Quantification ( $L O D$ and $L O Q$ )}

Analytical procedures for quantitation of major components of bulk drug substances or active ingredients (including preservatives) in finished pharmaceutical products are classified as category 1 . United States Pharmacopoeia states that LOD and LOQ test data elements are not required for this category [14].

\subsubsection{Robustness}

The robustness of an analytical procedure is the measure of method capacity to remain stable with relatively small amount of changes in method parameters [14]. Robustness test were evaluated by increasing the flow rate at $10 \%$ and increasing the temperature of the column for $5^{\circ} \mathrm{C}$. Table 11 shows the data of robustness tests including difference of the results as percentage.

Table 11. The results illustrating robustness test data for hypericins and valerenic acids.

\begin{tabular}{llll}
\hline Method & Normal Method & Flow Increased Method & Difference (\%) \\
\hline Hypericins Method & $300 \mathrm{mg}$ & $302 \mathrm{mg}$ & 0.66 \\
Valerenic Acids Method & $100 \mathrm{mg}$ & $101 \mathrm{mg}$ & 1.00 \\
\hline Method & Normal Method & Temperature Increased Method & Difference (\%) \\
\hline Hypericins Method & $300 \mathrm{mg}$ & $297 \mathrm{mg}$ & 1.00 \\
Valerenic Acids Method & $100 \mathrm{mg}$ & $101 \mathrm{mg}$ & 1.00 \\
\hline
\end{tabular}

\subsubsection{Solution stability}

Test solutions used in accuracy tests were kept in $4^{\circ} \mathrm{C}$ and $25^{\circ} \mathrm{C}$ in the dark for 48 hours and analysed again to achieve solution stability. Both hypericins and valerenic acids remained stable in the solution.

\subsection{Formulation stability}

Accelerated and long term stability tests were carried out to confirm the stability of the herbal product in primary packaging material according to ICH Q1A(R2); Stability testing of new drug substances and products guidelines [15]. Accelerated stability conditions were as follows; $40 \pm 2{ }^{\circ} \mathrm{C}, 75 \% \pm 5 \%$ R.H meanwhile long term stability conditions were $25 \pm 2{ }^{\circ} \mathrm{C}, 60 \% \pm 5 \%$ R.H. Table 12 shows the accelerated stability test results. Long term stability control test periods were $1,3,6,9,12,18$, 24th months and the results were in the limits. 
Table 12. Accelerated stability data.

\begin{tabular}{llccc}
\hline Product Specifications & \multicolumn{3}{c}{ Time Periods } \\
\hline Tests & Limits & $\begin{array}{c}\text { 1st } \\
\text { month }\end{array}$ & $\begin{array}{c}\text { 3rd } \\
\text { month }\end{array}$ & $\begin{array}{c}\text { 6th } \\
\text { month }\end{array}$ \\
\hline $\begin{array}{l}\text { Average Capsule } \\
\text { Weight }\end{array}$ & $500 \pm 7.5 \%$ & 498.27 & 501.36 & 500.84 \\
& $\begin{array}{l}500 \mathrm{mg} \pm 7.5 \% \text { (not more than 2 capsules } \\
\text { deviate from the average mass) }\end{array}$ & & & \\
Uniformity of & $\begin{array}{l}\text { Confirms } \\
\text { Weight }\end{array}$ & Confirms & Confirms \\
& Maximum 15 minutes & & \\
$\begin{array}{l}\text { Disintegration } \\
\text { Moisture (Karl }\end{array}$ & Maximum 3\% & Confirms & Confirms & Confirms \\
Fischer) & $300 \pm 30 \mathrm{mg}$ & $2.13 \%$ & $2.21 \%$ & $2.58 \%$ \\
$\begin{array}{l}\text { Assay (SJW) } \\
\text { Assay (VDE) }\end{array}$ & $100 \pm 10 \mathrm{mg}$ & $301 \mathrm{mg}$ & $298 \mathrm{mg}$ & $302 \mathrm{mg}$ \\
\hline
\end{tabular}

\subsection{Physical properties}

Disintegration tests of capsules were performed with a PTZ-S single basket tablet disintegrator (Pharma Test Apparatebau AG/Germany). All the capsules were disintegrated less than 15 minutes. A dissolution test was not reported in this study because disintegration is shown to be more discriminating than dissolution as stated by European Medicine Agency [16].

\section{CONCLUSION}

SJW also known as the herbal prozac is gaining popularity among with the herbal medicines. Valerian, on the other hand, has been used for its sedative properties for centuries. There are a lot of dietary supplements containing both SJW and VDE in the market but their quality is always questionable by comparison with the traditional herbal medicinal products. The following study demonstrates a stable oral formulation and a fully validated analytical method to comply the related parts of CTD could be used registering combined SJW and VDE in oral dosage form as traditional herbal medicinal product.

\section{MATERIALS AND METHODS}

Methanol, ethyl acetate, sodium dihydrogen phosphate, orthophosphoric acid and acetonitrile were purchased from Merck (Darmstadt, Germany). St. John's wort dry extract CRS and valerian root dry extract CRS were purchased from EDQM (Strasburg, France). EP grade St. John's wort quantified dry extract (0.19\% total hypericins by weight) and valerian root dry extract ( 0.45 total valerenic acids by weight) were purchased from Naturex (Avignon, France). All Naturex extracts were quantified with EDQM reference substances before using as raw materials. The methods were developed and validated using a Shimadzu HPLC Prominence (Kyoto, Japan) system coupled with a PDA detector. Columns were purchased from GLSciences (Japan) and Waters (USA). Parameters for both methods are listed in Table 1. Hitachi Aquacounter AQV 300 (Tokyo, Japan) was used to quantify water amount in the formulations during stability studies.

\subsection{Formulating and preparation of the dosage forms}

Unit formula of the dosage form is given in Table 2. Herbal extracts and the rest of the excipients were mixed for 20 minutes in a V-type mixer and size 0 capsules were filled with $500 \mathrm{mg}$ of bulk product using a Karnavati Minicap (Gujarat, India) capsule filling machine. Amber glass containers with plastic caps and silica gel (1.75 gram) desiccant were used as primary packaging material for 60 capsules.

Placebo for SJW was prepared by increasing the amount of maltodextrin to $390 \mathrm{mg}$ per capsule while placebo for valerian was prepared with $190 \mathrm{mg}$ maltodextrin. Placebos were used for specificity tests in method validations. Accuracy test samples were prepared according to Table 13. 
Table 13. Accuracy study sample formulations per capsule.

\begin{tabular}{lcccc}
\hline Ingredient & $\mathbf{8 0} \% \mathbf{S J W}$ & $\mathbf{1 2 0} \% \mathbf{S J W}$ & $\mathbf{8 0} \% \mathbf{~ V D E}$ & $\mathbf{1 2 0} \mathbf{0}$ VDE \\
\hline SJW Dry Extract (mg) & 240 & 360 & 300 & 300 \\
Valerian Root Dry Extract (mg) & 100 & 100 & 80 & 120 \\
Maltodextrine (mg) & 150 & 30 & 110 & 70 \\
Magnesium stearate (mg) & 5 & 5 & 5 & 5 \\
Silicon dioxide (mg) & 5 & 5 & 5 & 5 \\
TOTAL & 500 & 500 & 500 & 500 \\
\hline
\end{tabular}

\subsection{Assay method for hypericins}

Preparing the test solutions requires $225 \mathrm{mg}$ of the capsule content introduced into a $50 \mathrm{~mL}$ volumetric flasks and filled with $40 \mathrm{~mL}$ of methanol. After sonicating for 10 minutes and cooling to the room temperature flasks were filled up to the volume with methanol. Test solutions were filtered through a $50 \mu \mathrm{m}$ PTFE membrane filter into analytical vials and the vials were subjected to $765 \mathrm{~W} / \mathrm{m} 2$ Xenon lamp light for 10 minutes converting protohypericins to hypericins. After cooling to the room temperature the $20 \mu \mathrm{L}$ of the solutions were injected to HPLC system according to the method parameters described in Table 1.

Reference solutions were prepared same way except $70 \mathrm{mg}$ of SJW dry extract CRS was added in $25 \mathrm{~mL}$ volumetric flask.

To achieve the system suitability, resolution between pseudohypericin and hypericin should be 8-9 and the RSD \% of total hypericins areas sould be $\leq 2$ for two sequential reference solution injection. The amount of SJW could be calculated with the formula given in 2.2.4 Accuracy section.

\subsection{Assay method for valerenic acids}

To prepare the test solutions for valerenic acids, one capsule content was introduced into a $50 \mathrm{~mL}$ volumetric flask. Flask were filled with $40 \mathrm{~mL}$ of methanol and sonicated for 10 minutes. After cooling to the room temperature the flasks were filled up to the volume with methanol. Test solution were filtered through a $50 \mu \mathrm{m}$ PTFE membrane filter into an analytical vial and $20 \mu \mathrm{L}$ of the solutions were injected to HPLC system according to the method parameter given in Table $1 .$.

Reference solutions were prepared same way except $50 \mathrm{mg}$ of valerian dry extract CRS was added in 25 $\mathrm{mL}$ volumetric flask.

To achieve the system suitability, RSD\% of total valerenic acid (valerenic acid and acetoxyvalerenic acid) areas should be $\leq 2$ for two sequential reference solution injection. The amount of VDE in dosage forms could be calculated with the formula given in 2.2.4 Accuracy section. Figure 3. represents the chromatograms obtained from the final products.
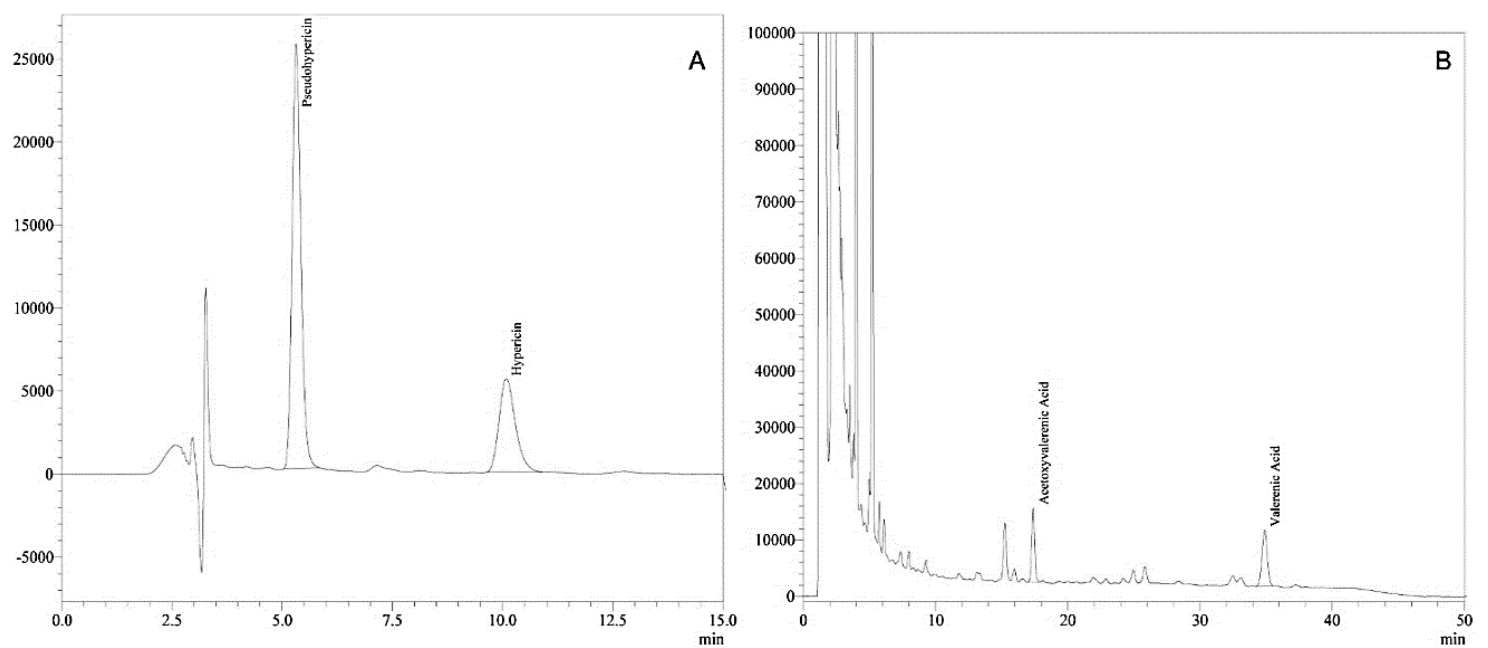

Figure 3. Chromatogram of (A) hypericins of SJW and (B) valerenic acids of VDE in final product. 


\subsection{Stability studies}

Accelerated and long term stability tests for products in primary packaging material were performed in a Binder KBF 115 (Tuttlingen, Germany) stability chamber. The conditions and sampling periods were described in 2.3 Formulation Stability section.

Author contributions: Concept - İ.D., M.K.; Design - İ.D., M.K.; Supervision - M.K.; Materials - İ.D., M.K.; Data Collection and/or Processing - İ.D., M.K.; Analysis and/or Interpretation - İ.D., M.K.; Literature Search - İ.D., M.K.; Writing - İ.D., M.K.; Critical Reviews - İ.D., M.K.

Conflict of interest statement: The authors declared no conflict of interest.

\section{REFERENCES}

[1] Redvers A, Laugharne R, Kanagaratnam G, Srinivasan G. How many patients self-medicate with St John's wort? Psychiatr Bull. 2001; 25(7): 254-256 [CrossRef]

[2] Clement K, Covertson C, Johnson M. J, Dearing K. St. John's wort and the treatment of mild to moderate depression: A systematic review. Holist Nurs Pract. 2006; 20(4):197-203.

[3] Community Herbal Monograph on Hypericum perforatum L. Herba. EMA/HMPC/101304/2008. European Medicines Agency, London, 2008.

[4] Grieve M. A Modern Herbal. Vol 2. New York, NY: Hafner Press; 1974: 824-830.

[5] Blumenthal M, Goldberg A, Brinckmann J. Herbal Medicine Expanded Commission E Monographs. Newton, MA: Integrative Medicine Communications; 2000: 394-400.

[6] Turner W. A New Herbal, Parts II and III. Cambridge, England: Cambridge University Press; 1995: 464-466.

[7] Ross SM. Psychophytomedicine: An Overview of Clinical Efficacy and Phytopharmacology for Treatment of Depression, Anxiety and Insomnia. Holist Nurs Pract. 2014; 28(4): 275-280. [CrossRef]

[8] European Union herbal monograph on Valeriana officinalis L., radix. EMA/HMPC/150848/2015. European Medicines Agency, London, UK, 2016.

[9] Council of Europe. St. John's Wort Quantified Dry Extract (01/2013:1874). European Pharmacopoeia $8^{\text {th }}$ edition. Strasbourg, France, 2013.

[10] Council of Europe. Valerian Dry Hydroalcoholic Extract (01/2011:1898). European Pharmacopoeia 8th edition. Strasbourg, France, 2013.

[11] International Conference on Harmonization ( $\mathrm{ICH}), \mathrm{ICH}$ M4; Organisation of the common technical document for the registration of pharmaceuticals for human use, Geneva, Switzerland, 2016.

[12] International Conference on Harmonization (ICH), ICH M4Q(R1); Organisation of the common technical document for the registration of pharmaceuticals for human use, Geneva, Switzerland, 2002.

[13] International Conference on Harmonization (ICH), ICH Q2(R1); Validation of Analytical Procedures: Text and methodology, Geneva, Switzerland, 2005.

[14] General Information / (1225) Validation of Compendial Procedures. United States Pharmacopeia and National Formulary (USP 41-NF 36). Rockville, MD: United States Pharmacopeial Convention; 2016.

[15] International Conference on Harmonization (ICH), ICH Q1A(R2); Stability Testing of New Drug Substances and Products, Geneva, Switzerland, 2003.

[16] Guideline on specifications: test procedures and acceptance criteria for herbal substances, herbal preparations and herbal medicinal products /traditional herbal medicinal products. EMA/CPMP/QWP/2820/00 Rev. 2. European Medicines Agency, London, UK, 2011. 